\title{
Out of Absurdity-On the Ending of Catch-22
}

\author{
YE La-mei \\ Shenzhen University, Shenzhen, China
}

\begin{abstract}
As one of the first and most original creations of literary postmodernism, published in the year 1961, Catch-22's (1961) position in American literature remains secure. Yet its ending has been held as unconvincing ever since its publication. Taking the overall structure, tone, and the theme of the novel into consideration, this paper aims to prove the credibility of this controversial part. It consists of five sections apart from an introduction and a conclusion. Section One provides general information on the life and works of Joseph Heller. Section Two traces the impact of existentialism and the generation of black humor to clarify the literary position of Catch-22. Section Three brings out the disputative opinions on the ending part. Sections Four and Five, try to prove Yossarian’s final desertion a natural and convincing ending from different perspectives: Section Four analyses how Yossarian gains an entropic vision of the cosmos; section Five studies his existential vision of physical life and searches for the immediate factors that propel Yossarian's desertion. Section five also explains the ending's change in tone and structure. The conclusion summarizes the paper and points out the social significance of the novel.
\end{abstract}

Keywords: absurdity, Catch-22, the ending

\section{Introduction}

By the end of the 50s, America, as the most powerful nation rising up after the Second World War, carried out "Police Action" in Vietnam and "Cold War" foreign policy; and domestically, it terrified the people with McCarthyism and the investigations of Un-American activities. The American intellectual culture was seen as oppressed and meanwhile restless. As the American historian Arthur Schlesinger put it, “ ...There is evident a widening restlessness, dangerous tendencies toward satire and idealisn1,a mounting dissatisfaction with the official priorities, a deepening concern with our character and objectives as a nation” (Potts, 1989, p. 5).

In such an environment, Catch-22 (1961) came out in the first year of Kennedy presidency. It proved to be an immediate success and its London edition was reprinted four times the first year. The book was successful because it really appealed to the mood of the readers of Heller's time. As the blurb inside the book jacket of the first hard-cover edition notes:

Catch-22 is like no other novel we have ever read. It has its own style, its own rationale, its own extraordinary character. It moves back and forth from hilarity to horror. It is outrageously funny and strangely affecting. It is totally original. (Heller, 1961)

However, the critics at that time disfavored the book for various reasons: the formless structure, the timeless illogical chronology, the repetition and monotony in language, the lack of traditional plot and characterization,

YE La-mei, master in literature and literary studies, associate professor, Foreign Language Institute, Shenzhen University. 
etc.. Whiney Balliett, for example, commented that Catch-22 is "not really a book.... It gives the impression of having been shouted onto paper” (Harris, 1971, p. 33). Indeed, few of Heller's contemporary critics was able to appreciate the valuable uniqueness of Catch-22. Not until the 1970s had the importance of the work been gradually recognized. It was then generally accepted that the book lacks neither in craft nor in form. It actually started a new genre in American literature-postmodernism. American critics agreed that the novel was not just "fitting loosely within the black humor genre, but the advance guard of a whole new approach to the novel, a movement now generally given the term 'postmodernism”' (Potts, 1989, p. 7).

With time passing by, Catch-22 has secured Joseph Heller a position in American literature. However, the ending part of the novel remains disputative: Many critics held that the description of Yossarian's desertion is a distortion of the tone, structure, and theme of the novel and therefore unconvincing.

The author of the present paper maintains that Catch-22 has its own logic of writing, Yossarian's final desertion fortifies the theme of searching for a meaningful existence, and the novel's structure and tone fully comply with the development of is theme. The thesis is an attempt to do justice to the novel's controversial ending.

\section{Joseph Heller: Life and Works}

Joseph Heller actually started his first novel Catch-22 in 1953 when the war had already been eight years away from him. He wrote the first section and then spent a whole year planning and preparing himself, using a unique system of note cards, which ran to an impressive amount of occupying the length of a shoe box. It took him altogether eight years to finish the book. Among Joseph Heller's other major works are: We Bombed in New Haven, a play performed in 1967; Something Happened in 1974, which is about a business executive undergoing pressures, fear, perplexities in peacetime; Good as Gold in 1979 about the Jewish family life; God Knows in 1984 about King David's reviews of his lifespan as well as Western, Judaic and Christian history to present; No Laughing Matter in 1986 (co-authored with Speed Vogel) telling of Heller's ordeal with Guilain Barre; and Picture This in 1988, focusing on Rembrandt's Holland and Aristotle's Athens.

Joseph Heller is modest in his aims as a wrier. He once observed in an interview originally carried on The Paris Review (fifth series, 1981), "I don't have a philosophy of life. ...my books are not constructed to 'say anything'”. He is probably being elusive for Catch-22 is actually a book humorous on the surface yet philosophical underneath. Heller simply gives the right of interpretation to his readers by such remarks. He is realistic about his skills, "I can be funny—for one half page at a time ... I can be humorous in several ways—with irony, with dialogue, with farcical situations, and occasionally with a lucky epigram or an aphorism” (Bayley, 1992, p. 6). Before his death, Heller was a professor at University of Pennsylvania.

\section{Catch-22, Existentialism and Black Humor}

Catch-22 is regarded as "one of the first and most original creation in literary postmodernism” (Potts,1989, p. 8). A survey of relationship with literary existentialism and black humor will help to clarify its significance in American literary history.

\section{A Summary of Catch-22}

Catch-22 is set in the final summer of Italian campaign in the Second World War. It combines naturalistic detail with surreal farce in style, and its time and space range throughout the lives of the characters. 
According to Potts (1989), the novel can be divided into five parts: Part one (sections 1-9) focuses on the U.S. Air Force Base-Pianosa; part two (sections 10-18) tells of the Great Big Siege of Bologna; part three (sections 19-25), bridging the midpoint of the novel, reflects different value systems: idealism, practical survivalism, self-seeking egoism,etc.; part four (sections 26-27) deals with events occurring between Pianosa and Rome; And part five (sections 38-42) is about Yosarian’s desertion.

\section{Catch-22, Existentialism and Black Humor}

When Catch-22 reached the British best-seller lists in its first year, critics still disfavored the book: They did not like the confusing plot and surreal exaggeration. Early critics failed to realize that $C$ atch-22 represented a new direction in American literature-postmodernism.

Heller's reading ranged from the classic 19th century novelists Dickens and Dostoyevsky to modernist William Faulkner, modern absurdist Nathanael West, and early postmodernist Vladimir Nabokov. The picaresque caricature of Yossarian reminds us of Charles Dickens. Around the time of reading Nabokov's blackly humorous Laughter in the Dark he discovered the avant-garde French writer Louis-Ferdinand Celine. The novel's avant-garde method of plot must have been inspired by Celine. Celine was known for his masterpiece Journey to the End of the Night (1990). The protagonist Ferdinand Bardamu in the novel is put in a wartime world with chaos, absurdity, and meaninglessness; he is indifferent to anything except his own survival. Heller explained that "Celine did things with time and structure, and colloquial speech I'd never experienced before", that "Journey to the End of the Night was the book that touched off" the conception of Catch-22 (Potts, 1989, p. 4). When he mentioned his beginning of writing the novel, he said that he thought of the opening two sentences and the overall tone and form of the book in an hour and a half:

I was lying in bed in my four-room apartment on the west side [of New York] when suddenly this line came to me: "It was love at first sight. The first time he saw the chaplain, Someone fell madly in love with him". ...as soon as the opening sentence was available, the book began to evolve clearly in my mind.... (Plimpton, 1981, p. 235)

Heller also insisted that its apparent chaotic plot was painstakingly constructed. Its abandoning of traditional novelistic techniques pointed to a new trend.

Many American writers around Heller's time "looked for guidance to Europe and French in particular, where they found the existentialist novels of Camus and Sartre” (Potts, 1989, p. 13). The existential vision of physical life that "Man is matter", read from Snowden's death by Yossarian in the novel, might be an evidence of the impact of existentialism at that time.

Therefore, Catch-22 not only represents a new direction in literature-postmodernism, but also reflected the influence of existentialism. A further expounding of the relationship between black humor and existentialism in literature will clarify Catch-22's position in literary history: "Black humor literature is similar to the literature of existentialism in that it begins with the same assumption — that the world is absurd” (Pratt, 1993, p. 1).

The philosophy of existentialism enjoyed a short term of popularity in America in the late 1940s and early 1950s. It derived from phenomenology. Among the existentialists, Jean-Paul Sartre and Albert Camus were two of the most influential to the American literary men, because "both men were superb novelists and dramatists as well as critics and philosophers... " (Leitch, 1988, p. 153). In the English version of his Existentialism, Sartre "outlined a handful of traits characteristic of the philosophy”, such as: "existence preceded essence"; "human 
beings had no essence and were thus obliged continuously to define existence"; "God did not exist”; "man would want but one thing freedom" (Leitch, 1988, p. 153). In The Wall, he expresses his idea that "the ridiculous and arbitrary termination of human life makes life itself similarly ridiculous and arbitrary”(Harris, 1971, p. 76). Existentialism best expressed the mood of French and European people after the serious wounding of the Second World War. People became skeptical of the existence of God. The world was no longer the one described in Robert Borrowing's famous lines_-“God's in his heaven-Al's right with the world!” On the contrary, the centre of western religion was Godless. The appearance of existentialism could be regarded as an utterance of such a crisis. As a novelist and critic, Sartre divided the problem of literature into three questions: What is writing? Why write? For whom does one write? (Horton, 1974, p. 495). It is quite easy for one to sense the air of crisis in such division. He also demanded that "literature be directed at changing the fundamental conditions of social existence” (Horton, 1974, p. 495). William Barrett noted in his The End of Modern Literature: Existentialism and Crisis (1990) that the crisis after the Second World War "places the writer in a precarious relation even to his craft". Guided by the philosophy of existentialism, Sartre produced his philosophical novel Nausea (1938), The Wall (1939), etc.; Camus produced The Plague (1947) and The Myth of Sisyphus (1942). Both writers described the contradiction of human existence. For example, Camus' The Myth of Sisyphus reflected the meaninglessness of human existence through comparing it to the punishment of Sisyphus in having to roll a huge rock eternally up a hill in Tartarus, only to see it plunge to the bottom again. However, Sisyphus is happy because "the struggle itself towards the heights is enough to fill a man's heart” (Horton, 1974, p. 510). This novel shows a reassertion of the meaning of human life. Generally speaking, existentialists' novels disclose the absurdity of the universe, meanwhile tend to be moral preaching. Viewed from an existentialist perspective, Yossarian's final desertion and his decision to collect the kid sister of Nately's whore on his way could be regarded as an elevation from his merely ego involvement to social involvement. In a sense, the ending of the novel conforms with the existentialist idea of service and responsibility:

By the end of the fifties, the neo-realist spirit and existentialist anxieties that had dominated the first part of the decade had already begun yielding to a new tone of black humor and absurdism,which was taking fiction away from realism. (Pratt, 1993, p. 1)

Black humor was born in the shadow of the function of existentialism yet pointed to a new trend in literature. It was conceived by modernism and gave birth to postmodernism.

As a new genre of literature, black humor was generated in an era when John F. Kennedy was elected president in 1960, when the Second World War was at a distance, when cold war was around between the US and Soviet competition in space exploration. "The writings of the sixties show a clear ret urn to politics and history, but not expressed in the form of a clear ideology nor in a devotion to social or proletarian realism" (Bradbury, 1987, p. 198). At the time when Joseph Heller started to compose the novel, the war had been eight years away. The mood of the time being Americans underwent a sharp change. Catch-22 should not be simply viewed as a war novel Heller himself observed in interviews that his novel was not intended as a criticism of World Wars, or initially even of war in general; that is, satire was aimed at the cold war of the 50s.

Black Humor involves the humorous treatment of what is grotesque, morbid, or terrifying. And while it bitterly ridicules institutions, value systems and traditions, black humor offers neither explicit nor implicit proposals for improving, reforming or changing the painful realties on which it focuses. (Pratt, 1993, p. 3) 
During eight years' composition, Heller adopted avant-garde literary techniques to best express the themes. as well as to construct the novel.

Heller's voice is a direct response to a world dominated by military institutions and systems, which cold war American had become. This is a world where sanity is madness, madness sanity, where the human is mechanical and the mechanical human, and such absurd formulae provide both the black humor and the structure of the book. (Bradbury, 1987, p. 212)

Another thing to be noted is that the term "black humor" was first coined by the French surrealist poet and critic Andre Breton in the late 1930s as "humor noir", the present term superseding "black humor" is "postmodernism"; "black humor "was only widely used in the 1960s. The term "postmodernism" tells us two things: "That modernism is over, and that the late modern arts still function in is shadow... " (Bradbury, 1987, p. 198). It describs a general tendency that in fiction "techniques grew random, styles mixed or merged, methods became increasingly provisional!” ( Bradbury, 1987, p. 198).

Heller's Catch-22 bears signs of existentialism in that it perceives the world as absurd and tries to reassert the meaning of human existence, but it is decidedly a work of black humor or postmodernism because its treatment of such serious themes is humorous and its anti-traditional novelistic techniques point to a new tendency in American literature.

\section{Disputative Opinions on the Ending}

One reason for the stature of Catch-22 remaining secure is that many of the attacks it received upon publication have been settled. Its value in literary postmodernism has been widely recognized. In spite of this, critical essays continue to be turned out, attempting to interpret the novel in various respects.

The critical essays on the novel mainly revolves around is technique or its message - the novel's tortured chronology or the satirical targets and theme. In 1967, Jan Solomon wrote an essay "The Structure of Joseph Heller's Catch-22", arguing that the novel has two opposing time lines: One is the cyclical line showing Yossarian's psychological perception of events and the existential vision of the universe; the other is the linear time line reflecting Milo's rising from a mess hall officer to the controller of an international cartel. Mio's linear time line cut randomly across Yossarian's cyclical line and explains the apparent formlessness of the novel's structure. Other critics defended its formlessness on the ground that is lack of a traditional chronological plot is consistent with the chaotic cosmos and lunatic logic of the story. In 1971, an essay entitled "Catch-22: A Radical Protest against Absurdity", carried on Contemporary Novelists of the Absurd, argued that "both the prose and the structure are carefully controlled,not only to reinforce the novel's theme of absurdity but to create their own dimension of absurdity as well” (Harris, 1971, p. 34). In 1974, Daniel Walden produced an essay proposing the interpretation of the novel in traditional Jewish terms. However, "the most frequent complaint made by supporters and detractors is the sudden twist in the last part of the novel” (Potts, 1989, p. 10). Waldmeir criticized the novel as flawed in is superficial complexity, real repetitiveness, and unconvincing ending. Many other critics who had come to appreciate the cosmos of Catch-22 meticulously constructed by Heller are also bothered by the apparent inconsistency of the ending part as com pared to the foregoing parts. They complained the last part was a distortion of the novel's tone and structure as well as the personality of Yossarian.

What's in the ending then? Are these critics doing it justice? 
The ending part covers five sections: section 38 "Kid Sister"-Yossarian breaks the news of Nately' s death to Natly's whore and is furiously attacked by the latter; section 39 "The Eternal City"-Learning that Rome is in ruins and the brothel has been raided, Yossarian gets worried about Nately' $\mathrm{s}$ whore and her kid sister and returns to Rome, only to find the degradation of human civilization; section 40 "Catch-22"-Back in Pianosa, Yossarian is tricked into signing an odious deal; section 41 "Snowden”-Injured by Nately's whore, Yossarian is sent to hospital recalling Snowden's death; and section 42 "Yossarian”-Yossarian explains his decision to break the deal and deserts after learning about Orr's reappearance in Sweden. In this part, Yossarian witnesses the misfortunes of children and women, feeling a compulsion to stop the chain of victim and culprit; he is morally woken up by the attack of Nately's whore, recalling the scene of Snowden's death; he starts a most serious talk with the idealist-Major Danby on the military system before the desertion.

Superficially at least, the ending represents a sharp change: The tone turns quite serious as Yossarian struggles over his final decision; the narrative becomes chronological except for the flashback of the section on Snowden; and Yossarian appears a totally new person as he begins to concern himself with social responsibilities, which is in sharp contrast to his original practical survivalism.

A critical and careful study of the novel, however, reveals that Yossarian's final desertion is just an apocalyptic choice owing to three factors (first, Snowden's death enables Yossarian to gain an existential vision of physical life; second, frequently confronted with the trap of Catch-22, he is woken up by the attack of Nately's whore before his totally falling into the tricky deal; third, Orr's persistence in fighting against the military system and his arrival at Sweden make a good example for Yossarian); the narrative tone has been darkening throughout the novel; and that the ending's turning chronological is decided by the need of thematic progression. Simply put, the ending represents a logical development of Yossarian's personality and a proper change in tone and structure.

\section{The Logic of Catch-22}

There are more than 70 characters in the novel, who are more or less related with the protagonist-Yossarian. Each of them represents an epitome of perspective on life and death. Many of their ideas clash with each other yet pivot around the logic of Catch-22. Witnessing his fellow airmen's responses to the rule of Catch-22, Yossarian gradually realizes the absurdity of military bureaucracy embodied in the "verbal trick" of Catch-22 and comes to a deep understanding of the absurd world in which the traditional values are inverted. Yossarian's entropic vision of the world of Catch-22 serves as a springboard for his decision to desert.

"Catch-22" as a term has come into the American daily speech since the novel's publication. It refers to the absurdity of any conditions in which choices are meaningless. In the novel, Catch-22 is itself "a verbal trick" (Bayley, 1992, p. 60), it shows up in many forms throughout the novel.

The term first appears when Yossarian decides to "go crazy" (Heller, 1961, p. 46). Yossarian goes to Doc Daneeka asking to be grounded, telling the latter he is crazy. The principle Doc Daneeka observes in life is "you scratch my back, and I'll scratch yours”, and “you do a favor for me, I’1l do one for you” (Heller, 1961, p. 34). He would have liked to help because Yossarian has helped him in avoiding routine flying missions by putting his name on flying records. But "there is the catch, the best one" (Heller, 1961, p. 46). It specifies "that a concern for one's own safety in the face of dangers that were real and immediate was the process of a rational mind" (Heller, 1961, p. 47). In other words, “if he flew them he was crazy and didn’t have to; but if he didn’t want to he was sane 
and had to” (Heller, 1961, p. 47). Doc Daneeka is helpless confronting the law of Catch-22, so is Yossarian.

Another scene focusing on the law of Catch-22 is in Rome. Rome is in ruins. The brothel is reduced to a shambles. "The girls were gone, the only one there was the old woman” (Heller, 1961, p. 415). It is the Military Policemen (M. P. s) who chase the girls away. When Yossarian questions why the M. P. s have the right to do so, the old woman answers that it is the rule of Catch-22 that allows them. Yossarian further demands whether the woman asks the M. p. s to read and show the law to them, the old woman replies that "they don't have to show us Catch-22. The law says they don't have to" (Heller, 1961, p. 416). Catch-22 seems to be a big trap lurking everywhere. The powerless have no hope of escaping from it. Everyone thinks the law is the supreme power and never doubts its existence. Yossarian, however, discovers "there was no such thing, Catch-22 did not exist, he was positive of that...", since "there was no object or text to ridicule or refute, to accuse, criticize, attack, amend, hate, revile, spit at, rip to shreds, trample upon or burn up” (Heller, 1961, p. 418). The law of Catch-22 is actually an operation principle of the whole bureaucratic system. It serves only those commanders' needs: their fame, profits, climbing up, dehumanized appetites ... It is not an established law. Yet it is the logic operating the whole military world. The immensity of its power also derives from the various forms which it is capable of carrying on. In the Avignon action, when Yossarian tries to find morphine in the first-aid kit, he finds a note instead, which says, "What's good for M \& M Enterprises is good for the country. Milo Minderbinder”. The medicine for saving lives in emergency has been taken away by Milo to make profits. The law Milo observes here is capitalism, the profit principle. It works fairly well within the logic of Catch-22 because every superior commander is ready to yield for profits at the expenses of the country's labors, properties, even the lives of those insignificant people.

Thus, Catch-22 is superficially a "verbal trick", while substantially a profit principle and an interest principle.

In the novel, there are three missions which Yossarian confronts with. Each leads him to a deeper understanding of war and mortality. He starts as an innocent, courageous bombardier at the debacle of Ferrara; then he changes into a "coward" continuously refusing to fly missions around the time of the Great Big Siege of Bologna, finally Snowden's death at Avignon mission leads him to an existential realization of human existence. Such changes of Yossarian's attitude toward war and death lay a good foundation for his final desertion.

Yossarian, who has already realized the pointlessness in continuing an ending war, publicly rebels after Nately's death. His rebellion annoys Colonel Cathcart and Colonel Korn, who plan to get rid of him eventually through a tricky deal. This part aims to prove that his choice of desertion is not unconvincing: Firstly, the attacks from Nately's whore are just like a koan in Zen which wakes him up to break the deal and brings him to a dead end; secondly, Orr's arrival at Sweden encourages Yossarian to desert since the idea of desertion has long been lingering on his mind before the Bologna mission. The action is delayed only because Yossarian has not had it planned out Orr's miraculous arrival at Sweden provides a good example for desertion.

After Nately's death, Yossarian refuses to fly any more missions. Colonel Cathcart wants to disappear him the way they disappear Dunbar. Colonel Korn suggests that he be sent to Rome and soothed with women and alcohol. In Rome, Yossarian breaks the news of Nately's death to Nately's whore, who is heartbroken and tries to stab him to death. Yossarian has to escape back to Pianosa. As he returns to the base, Captain Black tells him that Nately's whore has gone and M. P. s have raided the brothel Yossarian becomes worried about Nately's whore and her kid sister and returns to the city of Rome, expecting to save them. Rome is then in ruins. Yossarian 
experiences a night walk in the rain, witnessing the degradation of the city, where the logic of Catch-22 like an evil serpent is perishing everything.

Nately's whore was on his mind ... Snowden and Nately's whore's kid sister were on his conscience ... Yossarian thought he knew why Nately's whore held him responsible for Nately's death and wanted to kill him. Why the hel shouldn't she? It was a man's world, and she and everyone younger has every right to blame him and everyone older for every unnatural tragedy that befell them.... (Heller, 1961, p. 414)

In the long night walk, Yossarian begins to think about his responsibility for women and children, especially for Nately's whore and her kid sister. This change can be regarded as an existentialist moral strengthening. Yossarian starts to care about other people besides his own survival.

In chapter 40 "Catch-22", Yossarian gets involved in an odious catch. As is mentioned before, Yossarian is ordered to contract a deal with Colonel Cathcart and Colonel Korn. If he accepts the deal, he will be sent home yet suffer from a guilty con science; if not, he will have a clean conscience yet run the risk of being court-martialed. He decides to break the agreement after Nately's whore's attack, which, like a koan in Zen, brings him to a sudden realization of his responsibility. The existentialist responsibility, existentialist vision of human existence, together with the existentialist vision of the Universe- the world of Catch-22, bring Yossarian to a final decision of desertion. Nietzsche said, all the gods are dead, then man must become mature enough to assume the role. Man must be responsible for himself as well as women, children, and, finally, the whole society. Survival and responsibility, Yossarian embraces both.

Catch-22 is not a comic farce. It has a serious theme embodied not only in Yossarian's entropic vision of the cosmos but also in his final desertion. The description of the absurd world of Catch-22 is actually a preparation for the thematic progression in the ending part. Yossarian's final action is a natural and convincing development of his personality, a light of hope for his continuous quest for a meaningful existence.

Yossarian is to escape to Sweden, a neutral country covered with snow. Sweden seems "like the Paradise: sane people, plenty of good sex, a benevolent government, jolly drunkenness” (Karl, 1964, p. 138). Yossarian has been dreaming of this land for a long time, especially in the period before the Bologna mission is flown. He "waited for the piece of flak that would knock out one engine over the Italian Alps and provide him with the excuse for heading for Switzerland” (Heller, 1961, p. 318). He wants to scheme with a trusted pilot. Had it been possible he would have "preferred Sweden" (Heller, 1961, p. 318) because Sweden is the country "where the level of intelligence was high and where he could swim nude with beautiful girls... " and "have illegitimate Yossarians... launched into life without stigma” (Heller, 1961, p. 318) with the aid of the state. Here, Sweden is merely an imagination, a state of mind rather than a real place. It is often wondered whether there is another trap of Catch-22 awaiting Yossarian in Sweden. Some critics are sure that "when Yossarian reaches Sweden, he will be disappointed, even frustrated. Not all the tall, blonde women will capitulate, not all the people will be sane,the government will even expect him to work,and liquor will be expensive” (Karl, 1964, p. 138). Yet still Sweden remains valid as an idea, just as the mythical Byzantium is for William Butler Yeats. What is important is that it represents a hope, an alternative to falling victim to the rule of Catch-22. Yossarian may have desired a false Eden, but his deserting the hell for the paradise is certainly to be approved. 


\section{Tone and Structure}

For many critics who discredit Yossarian's final decision of desertion, the ending part represents too much of a change in tone and structure. The picaresque Yossarian, who has been whoring, lying and dodging flying missions in the interest of self-preservation throughout the story, suddenly becomes serious, straightforward and decent, with none of the cynical snideness left. The narrative also ceases to be confusing and becomes chronological. To these critics, such changes are too abrupt and not convincing.

Yet, given that Yossarian's desertion has been adequately prepared for and therefore represents a convincing development of his personality, as explained in previous sections, it would be safe to say that the critics failed to appreciate the change in tone and structure which actually complies with the progression of the theme. A close survey of the overall structure and tone as related to the theme would make this clear.

Catch-22 has been frequently criticized by early reviewers for being formless and chaotic. Anyone who has read beyond the novel's first section quickly becomes aware of its lack of a traditional chronological plot a close analysis of the narrative, however, reveals that it does have an intricate organization, that "beneath the apparent chaos of the story line exists a coherent sequence of events (Potts, 1989, p. 19). Based on the alteration of tone and the presence of de ja vu cycles (de ja vu is the feeling of having experienced something before), Potts came up with a sound division of the novel into five parts, as mentioned before. The following study of Part One is meant to disclose the general structure and tone of the novel.

Part One of the novel embraces the first nine sections, which focus on Yossarian's immediate circle in Pianosa. It begins with his hospital visit at the 44th mission and circles mostly around the late summer period of Avignon and the deaths of Snowden and Clevinger. It also flashes back to spring in Ferrara and the beginning of Milo's activities, and then back one year to Lieutenant Scheisskopf and Clevinger at Santa Ana, and further back to pick up the history of Major Major Major.

This account serves to offer a taste of the novel's apparent formlessness, which is to be followed throughout except in the ending. Many major events of the novel are heaped together but little is said of them. They are to reappear time and again in the following parts.

Nearly four-fifths of the novel is meticulously written to appear chaotic, as Heller insisted in a number of interviews. Why, then, did Heller take so much trouble to upset the time sequence of the novel?

The structure of the novel actually "internalizes and embodies the theme of avoidance” (Bayley, 1992, p. 56) Just as Yossarian skillfully evades flak barrage, the narrative circles round twice before getting to its target. It twists and dodges, spinning round and going backwards, trying to avoid being caught. The relationship between the structure and the theme is best expressed by Doug Gaukroger: "The unorthodox treatment of time in Catch-22 is both parallel to, and prepares the readers for, the unorthodox treatment of the subject matter. It is only fitting that a novel which deals with an apparently absurd and confused world should be written in an apparently absurd and confused style” (Potts, 1989, p. 27).

Subject matter decides the form or structure. This is also true of the ending part. In the last few sections, Yossarian undergoes substantial changes. The degradation of Rome and Nately's whore's furious attacks bring him to a moral awakening; his rejection of the odious deal, which is against the survivalism he has so far practiced, leads him to a dead end; Orr's miraculous arrival at Sweden strengthens his hope for an alternative-deserting the 
world of Catch-22.

Yossarian's decision of desertion represents a progression of the theme, and the novel needs a progression. Yossarian, once an absurd hero, becomes, not unconvincingly, a completely sane and decent man. He jumps out of the world of chaos and absurdity, and it is altogether fitting that Heller jumps out of the words of chaos and formlessness and returns to chronology.

The progression of theme also accounts for the novel's change of tone, which, in fact, has been darkening all the way.

It is widely agreed that the first few sections of Catch-22 are generally lighter in tone than those that follows. Heller's talents and skills in producing comic effect are fully demonstrated here.

\section{Repetition:}

"You're a chaplain”, he exclaimed ecstatically. "1 didn’t know you were a chaplain”.

"Why, yes”, the chaplain answered. "Didn't you know I was a chaplain?"

“Why, no. I didn’t know you were a chaplain” (Heller, 1961, p. 13).

\section{Contradiction or oxymoron:}

"Nately had a bad start. He came from a good family" (Heller, 1961, p. 13).

Wrenched cliché: "It was love at first sight" is promptly deflated by "The first time Yossarian saw the chaplain he fell madly in love with him” (Heller, 1961, p. 7).

\section{Meaningless or paradoxical choices:}

There was only one catch and that was catch-22, which specified that a concern for one's own safety in the face of dangers that were real and immediate were the process of a rational mind. Orr was crazy and could be grounded. All he had to do was ask; and as soon as he did, he would no longer be crazy and would have to fly more missions. Orr would be crazy to fly more missions and sane if he did not, but if he was sane he had to fly them. If he flew them he was crazy and didn't have to; but if he did not want to he was sane and had to (Heller, 1961, p. 47).

These comic devices appear with high frequency in Part One, but they are to alter in significances as the book progresses. Otherwise the book's humor will be trivial and redundant and gradually the readers will be bored.

By the end of the opening part, verbal repetitions and contradictions begin to "shift in function from mere stylistic devices to motifs embedded in the entire foundation of the book's structure” (Potts, 1989, p. 41). Repetition, for example, shows up in the recycling of certain scenes.

The repetition in structure merits attention. Each time a scene is repeated, more information is added and the scene grows in significance, and generally speaking, the tone of writing becomes darker. Snowden's death, for example, is mentioned but in one sentence-“"And Snowden lay dying in back” (Heller, 1961, p. 52), in section five, then a piecemeal description of the event is found in sections 21, 22, and 24. Yet it is not until section 41, the last but one section, that the whole matter is described in the mode of naturalism and becomes a thematic climax: Yossarian finally sees that physical life is all we have and there is no meaning in death.

In fact, the tone of the novel has always been darkening. Sections one through 28 offered the lightest comic touch, sections 29 through 37 are dominated by horrors, and the last five sections turned towards hope and guarded optimism. The change of tone is actually decided by the novel's serious theme. Catch-22 is a masterpiece of black humor. On the one hand, Heller tried his best to describe the absurdity of human existence, 
which evoked a lot of laughter in tears; on the other hand, he felt obliged to offer a hopeful alternative and left his readers with a call to actions, which is definitely serious. Had the tone been light and comic throughout, the novel would have been little more than a comic farce.

\section{Conclusion}

Catch-22 is above all an American novel. It shares many preoccupations with other American novels. These preoccupations have been summed up by Tony Tanner:

We may say that a central concern for the hero of many recent American novels is this: Can he find a freedom which is not a jelly, and can he establish an identity which is not a prison?! ...(And) the dilemma and the quest of the hero are often analogous to those of the author. Can he find a stylistic freedom which is not simply a meaningless incoherence, and can he find a stylistic form which will not trap him inside the existing forms of previous literature? (Tanner, 1971, p. 27).

It would be safe to say that Joseph Heller has found his stylistic freedom in Catch-22. Four-fifths of the novel is painstakingly constructed to appear formless and chaotic, which actually internalizes and embodies the theme of avoidance and creates a sense of absurdity. Underlying the comic effect ingeniously produced by Heller is the narrative tone which has been continuously darkening to remind the readers of the thematic seriousness. When it comes to Yossarian's decision of desertion, the thematic climax in the last five sections, Heller suddenly jumps out of the structural absurdity and shifts the narrative to chronology, and the tone accordingly becomes serious. The novel thus progresses as he intended.

Heller once told George Plimpton that "Catch-22" is concerned with physical survival against exterior forces or institutions that want to destroy life or moral self” (Potts, 1989, p. 111). This theme is embodied in Yossarian's quest for freedom and dignity.

Yossarian has a big appetite for life but finds himself in a world made hostile and irrational by ambitious power-seekers and greedy money-seekers. He sees everyday as a dangerous mission against mortality and struggles to keep himself alive. Yet the world of Catch-22 is also a compromised world. Victimizers-Colonel Cathcart, Mio and the like-meet with no substantial resistance in having their way, and victims of all kinds continue to die or wait for the doom. Yossarian is frustrated and helpless before the omnipresent Catch-22, offering little more than complaints and token resistance, followed by reluctant compliance. Yet even such token resistance irritates the self-seekers and he is offered a deal: to be their pals and sent home.

This is indeed a great temptation since it caters to Yossarian's survivalism. He accepts the deal but is promptly woken up by Nately's whore's attack. In hospital, he recalls the death of Snowden and the night walk in the ruined Rome, morality and responsibility prevail and he decides to break the deal, which seems to mean eternal damnation for him. Fortunately, Orr's miraculous arrival at Sweden provides him with an alternative, he deserts and leaps beyond the system of Catch-22.

The significance of Yossarian's desertion is that it provides hope for a meaningful existence: a life of dignity and freedom. Yet the readers have every reason to doubt Yossarian's redemption: No one can guarantee that Sweden is out of the reach of Catch-22.

Catch-22 is more than an anti-war novel although it has World War I as its background. It is rather a clear-cut satire on contemporary American life. Heller once told The Realist that he had meant the novel to "be as 
contemporary as possible” (Potts, 1989, p. 115). Later in the same interview, he complained of the transfer of wartime ideology to peacetime in America: "When this wartime emergency ideology is transplanted to peacetime,then you have this kind of lag which leads not only to absurd situations, but to very tragic situations" (Potts, 1989, p. 115).

Many Americans find the world described in Catch-22 depressingly familiar and the term "Catch-22" soon finds its way into the English language. It is nothing difficult for them to pick up scenes and languages characteristic of Heller's book: farcical episodes from the Vietnam War (1960s); Nixon's exemption from punishment for Watergate Scandal (1970s); CIA (Central Information Agency)—supported terrorists in Angola were called "freedom-fighters" (1980s); the invasion of Panama was termed "vertical insertion before dawn" (1990s). It is no wonder that Potts ends his book with such a statement: "We still live in the world of Catch-22" (Potts, 1989, p. 117).

Catch-22 is certainly a brilliant book in exposing the widespread ills of modern life: intolerance, bureaucracy, capitalism, racism, the greed for money and power. Heller leaves his book with a well-prepared hopeful ending, hoping that the world is a better place. Yet since his hero is only directed to desert and escape instead of taking actions against the absurd system, we see no strong cause for being optimistic.

\section{References}

Aldridge, J. W. (1983). The American novel and the way we live now. Oxford: Oxford University Press.

Bayley, N. (1992). York notes: Catch-22. Beijing: World Publishing Corporation.

Baym, N. (1989). The Norton anthology of American literature (Vol. 2). New York: W. W. Norton \& Company.

Bradbury, M. (1987). Contemporary American fiction. Cambridge: Cambridge University Press.

Coyle, M. (1993). Encyclopedia of literature \& criticism. Beijing: World Publishing Corporation.

Dictionary of literary biography (Vol. 28): Twentieth century American Jewish fiction writers. (1984). Detroit: Gate Research Company.

Falck, C. (1994). Myth, truth and literature: Towards a true post-modernism. New York: Cambridge Univ. Press.

Freadman, R. (1992). Re-thinking theory: A critique of contemporary literary theory and an alternative account. New York: Cambridge University Press.

Galoway, D. D. (1974). The absurd hero of American fiction. Austin: University of Texas Press.

Harris, C. B. (1971). Contemporary novelists of the absurd. New Haven: College \& Universiy Press.

Hassan, I. (1973). Contemporary American literature 1945-1972. New York: Frederic Ungar Publshing Co..

Heler, T. (1993). Notes on technique in black humor. Black humor: Critical essays. New York: Garland Publishing, Inc..

Heller, J. (1961). Catch-22. New York: Dell Publishing Co., INC..

Hifer, T. (1992). American fiction since 1940. London: Long man Group UK Ltd..

Horton, R. W. (1974). Backgrounds of American literary thought. New Jersey: Prentce-Hal, Inc..

Janoff, B. (1993). Black humor, existentialsm, and absurdiy: A generic confusion. Black humor: Critical essays. New York: Garland Publishing, Inc..

Karl, F. R. (1964). Joseph Heler's Catch-22: Only fools walks in darkness. Contemporary American novelists. Carbondale: Southern Illinois University Press.

Leitch, V. B. (1988). American literary criticism from the thirties to the eighties. New York: Columbia University Press.

Moore, H. T. (1964). Contemporary American novelists. Carbondale: Southern Illinois University Press.

Nash, C. (1993). World postmodern fiction: A guide. London: Longman Group UK Ltd..

O’ Neil, P. (1993). The comedy of entropy: The con texts of black humor. Black humor: Critical essays. New York: Garland Publishing, Inc..

Palmer, J. (1994). Taking humour seriously. London: Routledge.

Paul, S. L. (1989). Philosophical background to Western literature. Delhi: Sid Hartha Publisher.

Peek, C. A. (1967). Cliff notes: Catch-22. Nebraska: Incorporated Lincoln. 
Plimpton, G. (ed.). (1981). Writers at work: “The Paris Review” interviews, fifth series. Harmonds worth: Penguin Books. Potts, S. W. (1989). Antiheroic antinovel. Boston: Twayne Publshers.

Pratt, A. R. (1993). Black humor: Critical essays. New York: Garland Publishing, Inc..

Rubin, L. D. Jr. (1982). The comic imagination in American literature. Washington, D.C.: V. O. A..

Tanner,T. (1971). City of words: American fiction 1950-1970. New York: Harper \& Row Publisher. 